This item was submitted to Loughborough's Research Repository by the author.

Items in Figshare are protected by copyright, with all rights reserved, unless otherwise indicated.

\title{
City-dyad analyses of China's integration into the world city network
}

PLEASE CITE THE PUBLISHED VERSION

http://dx.doi.org/10.1177/0042098013494419

PUBLISHER

Sage Publications / @ Urban Studies Journal Limited

VERSION

AM (Accepted Manuscript)

LICENCE

CC BY-NC-ND 4.0

REPOSITORY RECORD

Taylor, Peter J., Ben Derudder, Michael Hoyler, Pengfei Ni, and Frank Witlox. 2019. "City-dyad Analyses of China's Integration into the World City Network". figshare. https://hdl.handle.net/2134/15291. 
This item was submitted to Loughborough's Institutional Repository (https://dspace.lboro.ac.uk/) by the author and is made available under the following Creative Commons Licence conditions.

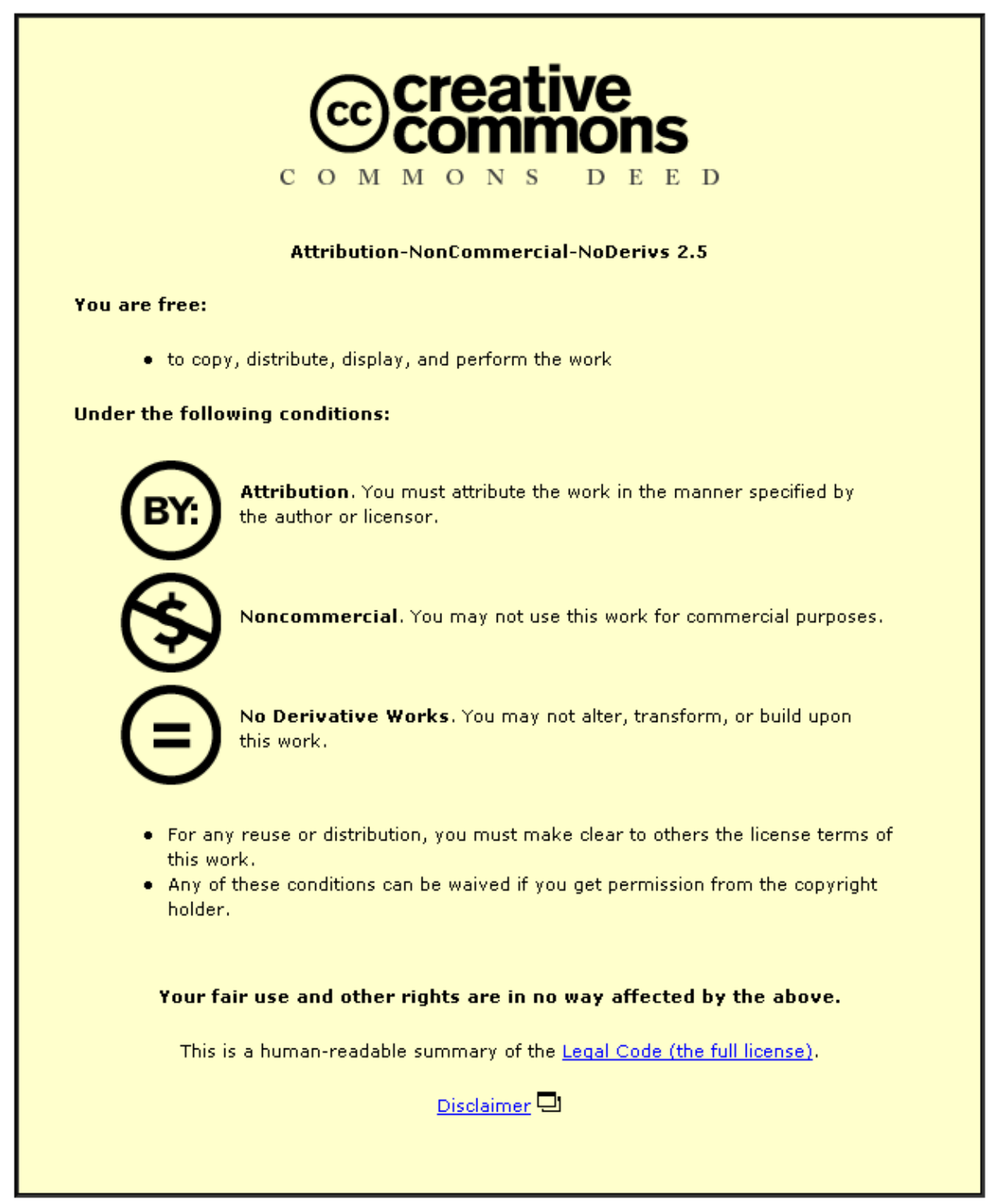

For the full text of this licence, please go to: http://creativecommons.org/licenses/by-nc-nd/2.5/ 


\title{
City-dyad analyses of China's integration in the world city network
}

\author{
Peter J. Taylor ${ }^{1}$, Ben Derudder ${ }^{2}$, Michael Hoyler ${ }^{3}$, Pengfei $\mathrm{Ni}^{4}$ and Frank Witlox ${ }^{2}$ \\ ${ }^{1}$ Faculty of Engineering and Environment, Northumbria University, \\ Newcastle upon Tyne NE1 8ST, UK \\ ${ }^{2}$ Department of Geography, Ghent University, Gent, B9000, Belgium \\ ${ }^{3}$ Department of Geography, Loughborough University, Loughborough LE11 3TU, UK \\ ${ }^{4}$ Chinese Academy of Social Sciences, Beijing, China
}

\begin{abstract}
The business connections between Beijing, Hong Kong and Shanghai and other major world cities are investigated using the interlocking network model based upon the location strategies of advanced producer service firms. This approach emphasises non-hierarchical relations between cities. A key new finding is that city-dyad analysis enhances the prominence of these China cities compared with simple ranking by total global network connectivity. This suggests that Hong Kong, Shanghai and Beijing have developed more strategically important roles in the world city network than previously understood. Yet the geographies of these links are distinctive, with Shanghai shown to be better connected to the more important world cities such as London and New York than Beijing; and Beijing is found to be better connected to political world cities such as Washington and Brussels, and to other Pacific Asian cities, than Shanghai. The results are interpreted as suggestions for developing a new research programme.
\end{abstract}

Key words: advanced producer services; China Cities, city-dyads, globalisation, world city network 


\section{Introduction}

In a recent paper on leading Chinese world cities, Karen Lai (2012) makes two key points about understanding cities in globalisation. First, she departs from the traditional hierarchical-competitive approach for understanding intercity relations ${ }^{1}$ and "foregrounds a relational perspective on intercity linkages and highlights complementary roles" (Lai, 2012 p. 1277). However, she adds the important caveat that hierarchical processes are not thereby dismissed, rather she "emphasises the complex co-existence of competition and collaboration" ( $p$. 1277). ${ }^{2}$ Second, she does not follow the recent spate of quantitative studies measuring intercity relations and prefers to conduct "intensive research (using) qualitative data" (p. 1279) to ascertain "how or why certain urban and economic processes take place in ... cities" (p. 1280). However, again her position includes a caveat, this time to the effect that quantitative researchers "have produced important results on city rankings and network structures" (p. 1279), implying a complementary relation between the two approaches. This suggests a critical realist methodology where extensive research provides input to intensive research (Sayer, 2002), which is confirmed by the way she starts her substantive contribution by drawing on previous quantitative results from Taylor (2006) (p. 1281).

We agree with both of Lai's qualified positions and we build upon them here in a very specific manner. In our interpretation of critical realist methodology the extensive research does not have to stop once it has provided ideas that only intensive research can properly examine; rather we view a spiral process where quantitative measures can return to refine further the network structures as suggested through the qualitative evidence and interpretation. In this case we identify from Lai's (2012) results and discussion a specific need for moving the focus of quantitative research from individual cities as the basic units of analysis to city-dyads. This brings actual intercity relations to the fore as a new focus in world city network analysis. Lai's primary findings concern how Shanghai relates to Beijing and Hong Kong; whereas there have been many 
commonplace views generating competitive narratives for these city-dyads ( $\mathrm{pp}$. 1275-1276), she finds more evidence for complementarities, termed "dualheadquarter strategy" (p. 1282) and "parallel markets" ( $p, 1286)$ respectively. The Beijing-Hong Kong dyad is not part of Lai's central concern but obviously features explicitly in her interpretation of the meaning to Hong Kong of being a Chinese 'autonomous area' (i.e. one step removed from Beijing's political power). In this paper we build upon Lai's (2012) initial use of quantitative results showing a simple ranking of China's three leading cities (Table 2, p. 1281); using a new world city network approach featuring city-dyad connectivities, we present an extensive investigation of Beijing-Hong Kong, Beijing-Shanghai and Hong Kong-Shanghai to complement her intensive research. Drawing on Sassen's (1991, pp. 3-4; 1994, p. 18) initial interpretation of "global cities" as "strategic places", which we link to Sheppard's (2002) concept of "geographical positionality", wherein he identifies Sassen's global cities as an example ( $p$. 324), we investigate how Hong Kong, Shanghai and Beijing have been positioning themselves in the world city network. Because city networks operate through mutuality it follows that instead of the rise of Shanghai and Beijing implying a decline in Hong Kong, the latter can continue to prosper through repositioning itself within the world city network. The geographies of these processes are shown through measures of the relative degrees of business connectivities between the three leading Chinese cities and other major world cities. In this manner, we take Lai's (2012) ideas forward to show in detail geographical outcomes of city repositionings empirically. Overall, the basic finding is that these leading China cities are strategically much more important in the world city network than their simple rankings suggest. This has both important implications for how we understand the ways in which China and nonChina cities link the Chinese space-economy to the global economy, and potentially profound consequences for how scholars treat the role of China in contemporary globalisation.

This is a theoretically informed empirical paper in which the argument is presented in five parts. We begin by outlining the interlocking network model of 
world cities that directs the data collection and underpins the analyses. Initial quantitative descriptions of Chinese cities and city-dyads that include Chinese cities are used to illustrate the model. The main substantive analyses are then laid out in the following order. We begin by displaying the disproportionate connectedness of Beijing, Hong Kong and Shanghai, which appears to be particularly emphasised through our focus on city-dyads. This confirms the specific importance of Hong Kong being not far behind London and New York in its connectivity. In the next section, we concentrate on the differences between the other two leading China cities; we are able to delineate quite distinctive patterns in the connectivities of their respective city-dyads. In the final substantive section, we trace changes from 2000 to 2010 in levels of connectivity between the three China cities plus London and New York to discover their various repositionings in the world city network. In a short conclusion, we provide some hints for turning our findings into questions for a new research programme for more intensive investigations.

\section{World City Network Analysis}

There is now a considerable literature on the role of cities as key nodes in an increasingly globalised economy. One expression of this can be found in recent large edited volumes: Scott (2001), Brenner and Keil (2006), Taylor et al. (2007, 2011, 2013) and Derudder et al. (2012) muster over 300 chapters between them but still represent only the tip of this particular iceberg. Amongst this body of research, the Globalization and World Cities (GaWC) Research Network ${ }^{3}$ has pioneered a relational approach to understanding cities in globalisation as a world city network. In developing a theoretically grounded measurement of world city network formation, we have drawn explicitly upon Sassen's (1991) seminal writings on the 'global city' as the prime production site and market for financial, professional and creative services for corporate business. Specifically, major firms across the world have become increasingly dependent on advanced producer services, such as financial services, accountancy, advertising, law and management consultancy which offer customised knowledge, expertise and 
skills to their corporate clients. In this process, many of these service firms have become transnational enterprises in their own right as they have expanded into a growing global market both to service their existing customers and acquire new clients (Aharoni and Nachum, 2000; Harrington and Daniels, 2006). According to Sassen (1991, p. 126) "global cities" have "a particular component in their economic base" that gives them a "specific role in the current phase of the world economy": they are the business service centres that have a key enabling role in economic globalisation.

\section{Data and Methods}

While world city network analyses are based upon Sassen's global city thesis, we depart from her approach in identifying more than just a select number of cities in the servicing of global capital. In this we follow Manuel Castells' (1996, p. 380) argument for a network society that encompasses a "global network" of cities that "cannot be reduced to a few urban cores at the top of the hierarchy". For the purpose of the large-scale empirical analyses reported here, the key point is that service firms have benefited immensely from the technological advances in telecommunications, allowing them to extend the geographical reach of their service provision. Thus while advanced producer service firms have always clustered in cities, in contemporary globalisation they have been able to do their work through multiple offices in large numbers of cities around the world. This enables them to protect their brand integrity and offer a 'seamless' service to their corporate clients operating in international markets (i.e. as opposed to previous instruments such as using 'correspondence banks' for clients' financial transactions). Each firm has its own strategy in terms of the location and number of cities in its office network, as well as the size and functions of individual offices. We employ an interlocking network model that treats the work done in these offices on projects that require multiple office inputs as 'interlocking' the cities in which they are housed. Thus these intercity relations through servicing practices consist of both electronic and embodied flows (for example, on-line exchange of information and sharing of knowledge, 
as well as face-to-face meetings involving business travel). It is these working flows', combined across numerous projects in many firms, that constitute the world city network as specified in the GaWC model (Taylor, 2001, 2004).

Specification of the model begins with formal representation as a city-by-firm matrix $\mathbf{V}_{i j}$, where $v_{i, j}$ is the 'service value' of city $i$ to firm $j$. This service value indicates the importance of a city within a firm's office network, which depends on the size and functions of a firm's office (or offices) in a city. From this service values matrix, the city-dyad connectivity $C D C_{a-i}$ between cities a and $i$ is defined as follows:

$$
C D C_{a-i}=\sum_{i} v_{a i} \cdot v_{i j} \quad(\text { where } a \neq i)
$$

This measures the potential working flows between any two cities within the world city network. It is based upon the assumption that the more important an office, the more working flows it generates; therefore flows between two cities with many large offices will be appreciably greater than flows between two cities with fewer large offices. For pedagogic and comparative reasons, in our following analysis, measures of $C D C_{a-i}$ are presented as percentages of the largest CDC, and therefore range from 0 per cent (for pairs of cities that have no firms in common) to 100 per cent for London-New York (the most connected city-dyad). This makes our results independent from the number of firms and cities in the analysis.

The global network connectivity $\left(G N C_{a}\right)$ of city a in this interlocking network is then derived from equation (1) by aggregating all the city's connectivities across the network:

$$
G N C_{a}=\sum C D C_{a-i} \quad(\text { where } a \neq i)
$$

For the same reasons given for equation (1), GNC measures are expressed as percentages of the largest computed connectivity in the data. Thus in our 
analysis, measures of $G N C_{a}$ range from 0 per cent (indicating cities where the firms have no offices) to 100 per cent for London (the most connected city).

To operationalise the interlocking network model requires data on the city office networks of large multilocational advanced producer service firms. We carried out a data collection in $\mathbf{2 0 1 0}$ on the location strategies of major firms in a number of key service sectors: financial services, accountancy, advertising, law and management consultancy. Firms were chosen by their ranking in lists of the largest firms in each sector; for financial services, the top 75 firms and for other service sectors we included the top 25 firms, giving a total of 175 firms. Cities were chosen on the basis of a number of overlapping criteria, whereby the selection is in part based on cities identified in previous GaWC research with additional cities based upon city size (all cities with populations over 2 million) and function (all capital cities of states with populations over a million). Thus 526 cities were selected. (For more details on firm and city selections see Taylor et al., 2011).

Assigning service values for the 175 firms' use of the 526 cities focused on two features of a firm's office(s) in a city as shown on their corporate websites: first, the size of office (for example, number of practitioners), and secondly, their extra-locational functions (for example, regional headquarters). The resulting multifarious compilation of information on firms was codified into service values ranging from 0 to 5 as follows. The city housing a firm's headquarters was scored 5; a city with no office of that firm was scored 0 . A typical office of the firm resulted in a city scoring 2; reasons for moving away from this score were: with something missing (for example, no partners in a law office), the score reduced to 1 ; with particularly large offices the score was raised to 3 ; and, with important extra-territorial functions (for example, regional headquarters) a score of 4 was recorded. All such assessments were made firm by firm. The end result is a 526 cities $\times 175$ firms matrix of 92,050 service values ranging between 0 an 5 , which can be used as the input to the interlocking network model as summarised in equations (1) and (2). 


\section{Introducing China Cities in World City Network Analysis}

In previous studies of the world city network, most of the focus has been on global network connectivity and Table 1 illustrates the results from equation (2) featuring the top 20 China cities in terms of this measure. World rankings are also shown and the main point of this table is to show the global importance of China's three leading cities, Hong Kong, Shanghai and Beijing in that order, followed by a long tail including many cities with limited connectivity into the world city network. In this paper, we concentrate on just these three cities; this becomes inevitable when we turn to the city-dyad analysis illustrated by Table 2. Here the results from using equation (1) are shown focusing on the top 20 city-dyads that include a China city. In this case, all dyads feature just the three main China cities (this would have remained the situation if we had included the top 250 city-dyads!) and they display much higher world rankings than shown in Table 1 . This is a first sign of the very strong integration of these cities into the world city network - 7 of the top 20 city-dyads across the world feature a Chinese city. In addition, the city-dyads linking China's three major cities all appear in this list. But in some ways this actually under-reports the role of the three cities in the world city network.

In Table 3, the top 20 city-dyads featuring China cities are listed in terms of their city-dyad relative connectivity (CDR). This is a city-dyad's connectedness relative to the two individual city's connectivity, indicated by the product of their global network connectivities:

$$
C D R_{a-i}=C D C_{a-i} /\left(G N C_{a} \cdot G N C_{i}\right) \quad(\text { where } a \neq i)
$$

This measures the relative concentration of the two cities' potential working flows in this particular dyad. High values indicate many firms choosing to locate offices, often important offices, in both cities suggesting extra business being conducted through this particular city-dyad; such city-dyads are relatively overconnected; we can think of them as 'punching above their weight' in 
interlocking the world city network; it indicates an enhanced 'strategic-ness'. The obverse is low values of CDR indicating few firms choosing to locate in both cities. Here we focus on the former. As with the other measures, these values in Table 3 are presented as percentages of the highest value. The basic message of this table is the overconnectedness of city-dyads including a China city: although the China cities are only 3 of the top 20 cities in terms of global network connectivity (Table 1), they feature in over half the top 38 highest overconnected city dyads. The three all-China city-dyads are ranked from 4th to 6th, which is a remarkable show of concentrated potential working flows. China's three leading cities certainly display all symptoms of being strategic places as conceived by Sassen. It is with this overconnectedness that we begin our detailed investigation of the way in which China is integrated into the world city network through its three leading cities.

\section{The Disproportionate Connectedness of Beijing, Hong Kong and Shanghai}

In Table 4 we have arrayed all the cities that are members of the top 40 citydyads in terms of relative connectivity against the leading 20 cities as measured by global network connectivity. We know from Table 3 that Hong Kong, Shanghai and Beijing feature prominently in these results; the new table provides the detailed geography of where concentrations of potential working flows are to be found across the world.

Since the global network connectivity of a city is constituted by the sum of its dyad connections (equations (1) and (2)) it follows that cities with higher levels of global network connectivity are likely to have more high dyad connectivities. This is clearly shown in Table 4 where the frequencies of relative overconnectedness tend to decrease as we go down the city rankings by global network connectivity. Yet this is by no means a simple definite tendency and the exceptions are particularly relevant. The extreme counter case contrasts Dubai and Frankfurt: the former city is ranked 9th for GNC but does not feature at all in 
overconnected dyads, whereas the latter ranked 19th is a member of 7 such dyads. Clearly, our city-dyad analysis is picking up patterns that are missed in a focus on total global network connectivity. It seems that the more firms locating in Dubai do not thereby generate strong links to other leading cities, whereas the fewer firms locating in Frankfurt are more geographically strategic to create several strong links to other major cities. Of course, Dubai is a city that has experienced massive commercial real estate development similar to China cities, but this parallel built environment growth hides a very different contribution to world city network formation. In stark contrast to Dubai, the three China cities are strongly overconnected, including all featuring among Frankfurt's strategic links.

Table 4 also shows that relative overconnection has a local geographical dimension. This confirms the 'regionality' within the world city network (Taylor et al., 2012): there are concentrations of strong intercity connections in worldregional (for example, Europe, Pacific Asia) and large-national (for example, USA, China) space-economies. Thus the first ranked city-dyad is Chicago-Los Angeles and Paris' strongest link is with London, Sydney's with Singapore, and Madrid's with Paris. Again this tendency is not universal: Frankfurt is actually most overconnected to Beijing! However, this general feature obviously accounts for the degree of overconnection in the all-China dyads. Yet this does not translate into a simple set of relations, and it is here that we begin to add geographical detail to Lai's (2012) discussion. For a start, Hong Kong is most overconnected to Singapore, followed by Shanghai and Beijing. Shanghai is most overconnected to Hong Kong, followed by Beijing - but the latter city ranks Shanghai before Hong Kong in overconnectedness. This suggests a rather subtle localism operating across the all-China city-dyads. In addition, we should note Tokyo's Pacific Asian strategic localism: it is most overconnected to the four other Pacific Asian cities in the table but with the three China cities ranked above Singapore. This particular localism is reinforced by London not featuring at all, and New York only in 40th place behind Los Angeles. Finally, we should not neglect Hong Kong's particular importance in this table: it is the 
most overconnected partner for three other cities, which is the most for any city in the table, two of which are not in China (Tokyo and Singapore) clearly suggesting not just Hong Kong as generally China's 'gateway city' (Taylor et al., 2002) but specifically as the hinge city between China and the rest of Pacific Asia.

The results from Table 4 are summarised in Table 5 where cities are ranked in terms of overconnected city-dyad membership. Global network connectivity ranks are also shown and confirm Frankfurt as the biggest 'riser' through the new analysis and Dubai as the biggest 'faller'. In terms of the three China cities: Hong Kong strongly continues in its position just below London and New York; Shanghai rises above Singapore to be 4th; and Beijing rises second-most places to 7th above Paris. Thus the key finding is that, in terms of strategic potential working flows, the China cities appear even more important than recent studies of global network analyses have indicated (Derudder et al., 2010; Hanssens et al., 2011; Taylor et al., 2011), and their flows strongly feature both intra-China and global connections.

\section{Contrasting Connections: Shanghai and Beijing}

Hong Kong is the established and continuing leading China city in the world city network but the relative positions of Shanghai and Beijing are still being constructed. In Table 6, differences between their respective city-dyads are explored to add further to our knowledge of the geographies of their network positioning. For this exercise, the top 50 cities in terms of GNC are included so as to go beyond Table 4 by presenting the geographies of Shanghai and Beijing's connectivity strengths amongst the other 48 leading cities.

The following findings can be gleaned from this table. First, although Beijing and Shanghai have similar numbers of cities tending towards each of them (25 and 23 respectively), Shanghai has more cities in the top 20 (11 to 7 ) and these are generally ranked higher including both London and New York. This is 
consistent with Shanghai having a larger GNC than Beijing but more crucially it shows Shanghai developing commercially as the more strategic place.

Second, the main geographical difference between Shanghai and Beijing's citydyads is that the latter include all Pacific city links (including two Australian cities) except for Hong Kong. This finding suggests a regional propensity for firms in western Pacific non-China cities to favour links to China's capital city. This is consistent with Wang et al.'s (2011) discussion of 'power and market' in how multinational firms choose where to locate their main China office, possibly with political considerations trumping commercial advantages.

Third, this political dimension is further supported by the tendency for capital cities to be linked more strongly to Beijing where there is more than one city from a country - Washington over New York, Delhi over Mumbai - and with city-states - Singapore and Dubai. The position of Washington being ranked first for Beijing over Shanghai is largely the result of leading law firms and their strategic need to be located in political cities.

Fourth, European cities are generally more strongly linked to Shanghai - 13 compared with 6 for Beijing. The latter include the European capital Brussels, the 'Eurasian capital' Moscow and more specialist financial centres notably Frankfurt, Zurich and Dublin.

Fifth, there is a more even distribution amongst US cities, 6 to 4 in Shanghai's favour but the latter consist of the top 5 US cities in terms of GNC plus Miami (7th ranked in US) the main link to Latin America.

Sixth, there are four Latin American cities in these data and they break 3 to 1 in favour of Shanghai, with São Paulo and Shanghai having particularly strong links. Finally, the only African city in these data, Johannesburg, is strongly linked to Beijing, possibly indicating a dependent relationship. Perhaps confirming the political nature of this link, Chinese service firms such as the 
China Construction Bank and the Bank of China feature strongly in its construction.

We can conclude that the distribution of Shanghai and Beijing's city-dyads have a clear structural pattern reflecting regional, political and GNC size influences.

\section{Changing Connections: 2000 to 2010}

Finally, we can take a tentative look at how city-dyad connectivities have been changing. This has to be cautious because, although we have been collecting data to create service value matrices from 2000, the methodology has been slightly modified as we have better understood the processes. The main difference is in terms of selection of firms and cities; the former has risen from 100 in 2000 to 175 in 2010 , the latter from 315 to 526 . It is the selection of firms that is most important for our results and in what follows we have reduced 2010 results by a factor of $100 / 175$ to create approximate comparable measures. For more details on these data differences see Derudder et al. (2010).

In Table 7, we present results showing change over the first decade of the 21 st century for just 10 major city-dyads, the three China city-dyads, their changing relations with London and New York, and the latter two cities' dyad as a base against which to compare. Taking each China city in turn, we can make the following statements about recent changes in their main world city network links.

The city of Shanghai records the largest growth in CDCs with each of the other cities under consideration. The biggest increase is with Beijing. This clearly shows the degree of growing importance of Shanghai's strategic-ness in the world city network.

The city of Beijing records the second-largest growth in CDCs with the other cities, at a level approximately half that of Shanghai. Note, however, that the 
strong link to Shanghai confirms the mutuality between the two cities: Shanghai's growth is feeding into Beijing and vice versa in a manner similar to that previously reported for London-Frankfurt relations (Beaverstock et al., 2005).

The city of Hong Kong shows CDC growth with the other China cities but records a reduction in CDC with London and New York. This should not be interpreted as Hong Kong declining in importance following its reincorporation into China in 1997. Rather, we have a reorientation of the city's position within the world city network: increases in potential working flows to Shanghai and Beijing more than make up for the smaller negative trend with London and New York. This is supported by the non-China city-dyad in Table 7; the London-New York CDC has declined at about the same rate as these cities' individual relations with Hong Kong. No one would suggest London and New York have declined in importance; rather, their orientations have moved slightly away from a North Atlantic fulcrum to other parts of the world where the world city network is intensifying, notably China where compensations in CDCs are shown with Shanghai and Beijing in Table 7. In other words, Hong Kong's links are trending like London and New York's; its repositioning is maintaining a very important strategic-ness within the world city network.

This change analysis confirms the previous 2010 findings that the leading three China cities have developed exceptionally as key strategic places within the world city network, albeit empirically with different relations towards other major world cities. These different geographies are not trivial; they imply intercity mutualities for the process of integrating the Chinese economy into the global economy.

\section{Conclusion}

In the world cities literature, there is only one city-dyad that has been widely researched: London-New York (Wójcik, 2013), which even has its own name, 
NY-LON (Smith, 2012). Thus Lai's (2012) intensive study of China's three leading cities as city-dyads is relatively unusual. In the introduction, we suggested that this new paper might be seen as an extensive complement to Lai's research in a research spiral of advancing understanding. It is the nature of extensive research that it cannot answer 'why questions', rather it shows patterns such as the findings presented in our tables. Such results should not be overinterpreted. Thus this conclusion will briefly consider where our research might be leading in terms of further intensive study. In other words, it is not so much about our findings as 'answers'; rather, this work should be evaluated in terms of bringing new questions to the fore.

Our contribution should be evident at two levels, the general and the specific. For the former, what our study has shown is that China cities are properly to be understood as part of a world city network. Lai's (2012) three city dyads are just as much part of this global structure as Chicago-Los Angeles, or indeed NYLON. From any single country focus, the world city network is not 'out there' featuring 'foreign cities' to compare to a so-called national urban system; rather, we are dealing with a transnational process, an interlocking network formation (Hoyler, 2011). Lai frames her study in terms of 'China's financial centre network', which is fine as long at it does not get filed away under 'China studies'. What she is describing are new emerging centralising tendencies in the world city network challenging previous centralising (NY-LON). Of course, she is fully aware of this wider context; some of her fieldwork was carried out in London and she explicitly refers to the extra-China work experiences of her interviewees (p. 1280). The results in this paper show the need for a transnational framework in studying contemporary city-dyads - that is to say, filing under 'global studies'.

Beyond framing research there are the specific findings that require further intensive investigation about why and how the world city network makers, leading advanced producer service firms, are developing their intercity office 
networks the way they are. Here are six findings that we believe deserve further analysis:

(1) There is the interesting contrast between the China cities and Dubai in terms of major dyad links despite similarities in their capital investments in real estate (where the high cranes are). Has this made China cities more resilient and if so exactly how?

(2) Beijing's dyads appear to be more political than Shanghai's. What specifically is this political process within world city network formation?

(3) Beijing is particularly well connected to other western Pacific cities. Does this indicate initial signs of dependency relationships and if so what forms might this take?

(4) Shanghai has stronger relations with more important cities across the world than Beijing. Does this make Shanghai's position more resilient and what might this mean?

(5) Shanghai has more rapid growth in connectivity than the other two China cities. How sustainable is this - are we at the beginning or near the end of the process?

(6) Hong Kong appears to have been successfully repositioning itself. What exactly does this mean for the firms operating through Hong Kong?

Positing these questions points towards a new research agenda for developing a new understanding of the role of Chinese cities in a globalising world. In sum, we trust that other studies will treat our findings as a foundation upon which to build theoretically-informed and policy-relevant knowledge. 


\section{Acknowledgements}

The authors wish to thank their co-researchers Kathy Pain and Sandra Vinciguerra for help with initial work developing the dyad analysis approach. They also wish to thank Hank V. Savitch and three anonymous referees who made useful suggestions for improving the manuscript. The usual disclaimers apply.

\section{Funding}

The authors thank the Economic and Social Research Council for supporting the initial work developing the dyad analysis approach (RES-000-22-3575).

\section{Notes}

${ }^{1}$ Recent examples for China cities include Shi and Hamnett (2002), Yusuf and Wu (2002), Zhao (2003) and Wang et al. (2007).

2 For a similar argument, see also Sassen (1999), Beaverstock et al. (2005), Taylor (2012, 2013) and Wójcik (2013).

${ }^{3}$ See: www.lboro.ac.uk/gawc.

\section{References}

Aharoni, Y. and Nachum, L. (2000) Globalization of Services: Some Implications for Theory and Practice. London: Routledge.

Beaverstock, J. V., Hoyler, M., Pain, K. and Taylor, P. J. (2005) Demystifying the euro in European financial centre relations: London and Frankfurt, 20002001, Journal of Contemporary European Studies, 13(2), pp. 143-157.

Brenner, N. and Keil, R. (Eds) (2006) The Global Cities Reader. London: Routledge.

Castells, M. (1996) The Rise of the Network Society. Oxford: Blackwell. 
Derudder, B., Hoyler, M., Taylor. P. J. and Witlox, F. (Eds) (2012) International Handbook of Globalization and World Cities. Cheltenham: Edward Elgar.

Derudder, B., Taylor, P. J., Ni, P., De Vos, A., Hoyler, M., Hanssens, H., Bassens, D., Huang, J., Witlox, F., Shen, W. and Yang, X. (2010) Pathways of change: shifting connectivities in the world city network, 2000-08, Urban Studies, 47(9), pp. 1861-1877.

Hanssens, H., Derudder, B., Taylor, P.J., Hoyler, M., Ni, P., Huang, J., Yang, X. and Witlox, F. (2011) The changing geography of globalized service provision, 2000-2008, The Service Industries Journal, 31(14), pp. 22932307.

Harrington, J. W. and Daniels, P. W. (Eds) (2006) Knowledge-based Services, Internationalization and Regional Development. Aldershot, UK: Ashgate.

Hoyler, M. (2011) External relations of German cities through intra-firm networks - a global perspective, Raumforschung und Raumordnung, 69(3), pp. 147-159.

Lai, K. (2012) Differentiated markets: Shanghai, Beijing and Hong Kong in China's financial centre network, Urban Studies, 49(6), pp. 1275-1296.

Sassen, S. (1991) The Global City: New York, London, Tokyo. Princeton, NJ: Princeton University Press.

Sassen, S. (1994) Cities in a World Economy. Thousand Oaks: Pine Forge Press.

Sassen, S. (1999) Global financial centers, Foreign Affairs, 78(1), pp. 75-87.

Sayer, A. (2002) Method in Social Science: A Realist Approach. London: Routledge.

Scott, A. J. (Ed.) (2001) Global City-Regions: Trends, Theory, Policy. Oxford: Oxford University Press.

Sheppard, E. (2002) The spaces and times of globalization: place, scale, networks, positionality. Economic Geography, 78(3), pp. 307-330.

Shi, Y. and Hamnett, C. (2002) The potential and prospect for global cities in China: in the context of the world system, Geoforum, 33(1), pp. 121-135. 
Smith, R. G. (2012) NY-LON, in: B. Derudder, M. Hoyler, P. J. Taylor and F. Witlox (Eds) International Handbook of Globalization and World Cities, pp. 421-428. Cheltenham: Edward Elgar.

Taylor, P. J. (2001) Specification of the world city network. Geographical Analysis, 33(2), pp. 181-194.

Taylor, P. J. (2004) World City Network: A Global Urban Analysis. London: Routledge.

Taylor, P. J. (2006) Shanghai, Hong Kong, Taipei and Beijing within the world city network: positions, trends and prospects. GaWC Research Bulletin No. 204 (www.lboro.ac.uk/gawc/rb/rb204, accessed 1 July 2012).

Taylor, P. J. (2012) On city cooperation and city competition, in: B. Derudder, M. Hoyler, P. J. Taylor and F. Witlox (Eds) International Handbook of Globalization and World Cities, pp. 51-63. Cheltenham: Edward Elgar.

Taylor, P. J. (2013) Extraordinary Cities: Millennia of Moral Syndromes, Worldsystems and City/State Relations. Cheltenham: Edward Elgar.

Taylor, P. J., Derudder, B., Saey, P. and Wilox, F. (Eds) (2007) Cities in Globalization: Practices, Policies and Theories. London: Routledge.

Taylor, P. J., Walker, D. R. F., Catalano, G. and Hoyler, M. (2002) Diversity and power in the world city network, Cities, 19(4), pp. 231-241.

Taylor, P. J., Derudder, B., Hoyler, M. and Ni, P. (2013) New regional geographies of the world as practised by leading advanced producer service firms in 2010, Transactions of the Institute of British Geographers, 38(3), pp. 497-511.

Taylor, P. J., Hoyler, M., Beaverstock, J. V., Faulconbridge, J. R., Derudder, B., Witlox, F., Harrison, J. and Pain, K. (Eds) (2013) Global Cities (4 vols). London: Routledge Major Works.

Taylor, P. J., Ni, P., Derudder, B., Hoyler, M., Huang, J. and Witlox, F. (Eds) (2011) Global Urban Analysis: a Survey of Cities in Globalization. London: Earthscan.

Wang, D. T., Zhao, S. X. and Wang, D. (2007) Information hinterland - a base for financial centre development: the case of Beijing versus Shanghai in 
China, Tijdschrift voor Economische en Sociale Geografie, 98(2) pp. 102120.

Wang, D. T., Zhao, S. X., Gu, F. F. and Chen, W. Y. (2011) Power or market? Location determinants of multinational headquarters in China, Environment and Planning A, 43(10), pp. $2364-2383$.

Wójcik, D. (2013) The dark side of NY-LON: financial centres and the global financial crisis. Urban Studies, DOI: 10.1177/0042098012474513.

Yusuf, S. and Wu, W. (2002) Pathways to a world city: Shanghai rising in an era of globalisation, Urban Studies 39(7), pp. 1213-1240.

Zhao, S. X. B. (2003) Spatial restructuring of financial centers in mainland China and Hong Kong: a geography of finance perspective, Urban Affairs Review, 38(4), pp. 535-571. 
Table 1. Top 20 Chinese cities for global network connectivity

\begin{tabular}{|c|c|c|c|}
\hline China rank & World rank & City & $G N C^{*}$ \\
\hline 1 & 3 & Hong Kong & 73.0 \\
\hline 2 & 7 & Shanghai & 62.7 \\
\hline 3 & 12 & Beijing & 58.4 \\
\hline 4 & 43 & Taipei & 41.7 \\
\hline 5 & 67 & Guangzhou & 34.1 \\
\hline 6 & 106 & Shenzhen & 25.8 \\
\hline 7 & 188 & Tianjin & 16.8 \\
\hline 8 & 223 & Kaohsiung & 14.3 \\
\hline 9 & 245 & Nanjing & 13.5 \\
\hline 10 & 252 & Chengdu & 13.1 \\
\hline 11 & 262 & Hangzhou & 12.5 \\
\hline 12 & 267 & Qingdao & 12.3 \\
\hline 13 & 275 & Dalian & 12.0 \\
\hline 14 & 291 & Macao & 10.9 \\
\hline 15 & 319 & Chongqing & 8.9 \\
\hline 16 & 323 & Xi'an & 8.7 \\
\hline 17 & 325 & Suzhou & 8.6 \\
\hline 18 & 337 & Wuhan & 8.0 \\
\hline 19 & 346 & Xiamen & 7.5 \\
\hline 20 & 348 & Ningbo & 7.5 \\
\hline
\end{tabular}

*GNC is global network connectivity and is presented as percentage of the most connected city (London). 
Table 2. Top 20 city-dyads that include China cities

\begin{tabular}{ccll} 
China rank & World rank & \multicolumn{1}{c}{ City-dyad } & CDC* \\
1 & 2 & Hong Kong and London & 75.0 \\
2 & 3 & Hong Kong and New York & 69.0 \\
3 & 6 & London and Shanghai & 62.1 \\
4 & 10 & New York and Shanghai & 58.7 \\
5 & 14 & Beijing and London & 55.6 \\
6 & 19 & Beijing and New York & 52.3 \\
7 & 20 & Hong Kong and Singapore & 51.6 \\
8 & 31 & Hong Kong and Shanghai & 47.5 \\
9 & 32 & Hong Kong and Paris & 47.2 \\
10 & 37 & Hong Kong and Tokyo & 44.9 \\
11 & 39 & Beijing and Hong Kong & 43.9 \\
12 & 44 & Shanghai and Singapore & 41.1 \\
13 & 45 & Paris and Shanghai & 40.4 \\
14 & 46 & Dubai and Hong Kong & 39.8 \\
15 & 47 & Chicago and Hong Kong & 39.7 \\
16 & 50 & Hong Kong and Sydney & 39.2 \\
17 & 52 & Beijing and Singapore & 38.8 \\
18 & 54 & Shanghai and Tokyo & 38.4 \\
19 & 56 & Beijing and Shanghai & 38.0 \\
20 & 57 & Hong Kong and Milan & 37.0
\end{tabular}

${ }^{*} \mathrm{CDC}$ is city-dyad connectivity and is shown as percentage of the most connected city dyad (London-New York) - see equation (1). All China citydyads are emboldened. 
Table 3. Top 20 city-dyad overconnections that include China cities

\begin{tabular}{cclc} 
China rank & World rank & \multicolumn{1}{c}{ City-dyad } & $C D O^{*}$ \\
1 & 3 & Hong Kong and Singapore & 97.4 \\
2 & 4 & Hong Kong and Shanghai & 96.4 \\
3 & 5 & Beijing and Shanghai & 96.4 \\
4 & 6 & Beijing and Hong Kong & 95.7 \\
5 & 7 & Hong Kong and London & 95.5 \\
6 & 9 & Hong Kong and New York & 93.0 \\
7 & 10 & New York and Shanghai & 92.1 \\
8 & 12 & London and Shanghai & 91.9 \\
9 & 14 & Beijing and Singapore & 91.6 \\
10 & 16 & Beijing and Frankfurt & 90.2 \\
11 & 17 & Shanghai and Singapore & 90.1 \\
12 & 19 & Hong Kong and Tokyo & 89.6 \\
13 & 21 & Beijing and Tokyo & 89.3 \\
14 & 25 & Shanghai and Tokyo & 89.2 \\
15 & 26 & Frankfurt and Hong Kong & 89.1 \\
16 & 29 & Beijing and London & 88.5 \\
17 & 33 & Beijing and New York & 88.2 \\
18 & 35 & Hong Kong and Paris & 88.0 \\
19 & 37 & Paris and Shanghai & 87.6 \\
20 & 38 & Frankfurt and Shanghai & 87.1
\end{tabular}

${ }^{*} \mathrm{CDO}$ are measures of city-dyad overconnections presented as percentages of the largest overconnection (Chicago-Los Angeles). Only cities in the top 20 of global network connectivity are included. All China dyads are emboldened. 
Table 4. The main dyad partners of the top 20 cities

\begin{tabular}{|c|c|c|c|c|c|c|c|c|c|c|c|}
\hline $\begin{array}{l}G N C \\
\text { rank }\end{array}$ & City & $\begin{array}{l}\text { Dyad-partners } \\
\text { with rankings }\end{array}$ & & & & & & & & & \\
\hline 1 & London & 2 New York & 7 Hong Kong & 12 Shanghai & 13 Singapore & 18 Paris & 22 L. Angeles & 24 Chicago & 28 Frankfurt & 29 Beijing & \\
\hline 2 & New York & 2 London & 8 L. Angeles & 9 Hong Kong & 10 Shanghai & 11 Chicago & 15 Singapore & 23 Frankfurt & 31 Paris & 32 Beijing & 40 Tokyo \\
\hline 3 & Hong Kong & 3 Singapore & 4 Shanghai & 6 Beijing & 7 London & 9 New York & 19 Tokyo & 26 Frankfurt & 33 Paris & & \\
\hline 4 & Paris & 18 London & 20 Frankfurt & 31 New York & 33 H. Kong & 35 Shanghai & 37 Madrid & & & & \\
\hline 5 & Singapore & 3 Hong Kong & 13 London & 14 Beijing & 15 New York & 17 Shanghai & 27 Tokyo & 30 Sydney & 38 Frankfurt & & \\
\hline 6 & Tokyo & 19 H. Kong & 21 Beijing & 25 Shanghai & 27 Singapore & 34 L. Angeles & 40 New York & & & & \\
\hline 7 & Shanghai & 4 Hong Kong & 5 Beijing & 10 New York & 12 London & 17 Singapore & 25 Tokyo & 35 Paris & 36 Frankfurt & & \\
\hline 8 & Chicago & $1 \mathrm{~L}$. Angeles & 11 New York & 24 London & & & & & & & \\
\hline 9 & Dubai & & & & & & & & & & \\
\hline 10 & Sydney & 30 Singapore & & & & & & & & & \\
\hline 11 & Milan & & & & & & & & & & \\
\hline 12 & Beijing & 5 Shanghai & 6 Hong Kong & 14 Singapore & 16 Frankfurt & 21 Tokyo & 32 New York & & & & \\
\hline 13 & Toronto & & & & & & & & & & \\
\hline 14 & São Paulo & & & & & & & & & & \\
\hline 15 & Madrid & 37 Paris & & & & & & & & & \\
\hline 16 & Mumbai & & & & & & & & & & \\
\hline 17 & Los Angeles & 1 Chicago & 8 New York & 22 London & 14 Tokyo & & & & & & \\
\hline 18 & Moscow & & & & & & & & & & \\
\hline 19 & Frankfurt & 16 Beijing & 20 Paris & 23 New York & 26 H. Kong & 28 London & 29 London & 36 Shanghai & 38 Singapore & & \\
\hline 20 & Mexico City & & & & & & & & & & \\
\hline
\end{tabular}

Note: The top 40 city-dyads are included as measured by city-dyad relative connectivity - see equation (3). 
Table 5. Top 20 GNC cities ranked by top 40 dyad memberships

\begin{tabular}{lccc}
\multicolumn{1}{c}{ City } & $\begin{array}{c}\text { Dyad } \\
\text { memberships }\end{array}$ & $\begin{array}{c}\text { Membership } \\
\text { rank }^{* *}\end{array}$ & GNC rank \\
New York & 10 & 1 & 2 \\
London & 9 & 2 & 1 \\
Hong Kong & 8 & 3 & 3 \\
Shanghai & 8 & 4 & 7 \\
Singapore & 8 & 5 & 5 \\
Frankfurt & 8 & 6 & 19 \\
Beijing & 7 & 7 & 12 \\
Paris & 7 & 8 & 4 \\
Tokyo & 6 & 9 & 6 \\
Los Angeles & 4 & 10 & 17 \\
Chicago & 3 & 11 & 8 \\
Sydney & 1 & 12 & 10 \\
Madrid & 1 & 13 & 15 \\
Toronto & $0(59)$ & 14 & 13 \\
Mumbai & $0(67)$ & 15 & 16 \\
Milan & $0(100)$ & 16 & 11 \\
São Paulo & $0(109)$ & 17 & 14 \\
Moscow & $0(120)$ & 18 & 18 \\
Dubai & $0(132)$ & 19 & 9 \\
Mexico City & $0(174)$ & 20 & 20
\end{tabular}

*For cities with zero membership in the top 40, their highest ranked dyad membership is given in brackets to be used in ranking.

${ }^{* *}$ For cities with dyad membership that have equal totals, they are ranked by their lowest average of ranks from Table 4. 
Table 6. Relative strengths of Shanghai and Beijing in city-dyads with other top 50 GNC cities

\begin{tabular}{|l|c|l|c|}
\hline $\begin{array}{c}\text { Cities tending } \\
\text { towards Shanghai }\end{array}$ & Difference $^{*}$ & $\begin{array}{c}\text { Cities tending } \\
\text { towards Beijing }\end{array}$ & Difference $^{*}$ \\
\hline Munich & 1.09 & Washington & -0.86 \\
Milan & 1.04 & Seoul & -0.73 \\
Madrid & 1.01 & Dublin & -0.66 \\
São Paulo & 0.81 & Kuala Lumpur & -0.52 \\
Santiago & 0.70 & Johannesburg & -0.50 \\
Mumbai & 0.69 & Frankfurt & -0.48 \\
New York & 0.61 & Melbourne & -0.34 \\
London & 0.53 & Moscow & -0.30 \\
Lisbon & 0.52 & Dallas & -0.24 \\
Stockholm & 0.51 & Atlanta & -0.23 \\
Warsaw & 0.51 & Singapore & -0.23 \\
Prague & 0.46 & Philadelphia & -0.22 \\
Miami & 0.46 & Brussels & -0.20 \\
Istanbul & 0.37 & Zurich & -0.19 \\
Boston & 0.32 & Delhi & -0.16 \\
Barcelona & 0.30 & Dubai & -0.16 \\
Paris & 0.24 & Taipei & -0.13 \\
Vienna & 0.23 & Bangkok & -0.12 \\
Los Angeles & 0.17 & Mexico City & -0.10 \\
Buenos Aires & 0.15 & Sydney & -0.09 \\
Hong Kong & 0.11 & Jakarta & -0.08 \\
San Francisco & 0.09 & Tokyo & -0.03 \\
Toronto & 0.07 & Düsseldorf & -0.00 \\
Amsterdam & 0.01 & & \\
Chicago & 0.00 & & \\
\hline
\end{tabular}

*Difference is computed as $\left(C D R_{\text {Shanghai-i }}-C D R_{\text {Beijing-i }}\right)$. These values are very small and therefore they are multiplied by 10,000 for presentation). Top 20 GNC cities are emboldened. 
Table 7. Changes in city-dyad connectivity, 2000-10

$\begin{array}{lr}\quad \text { City-dyads } & \text { CDC \% change } \\ \text { Beijing-Shanghai } & 69.40 \\ \text { Hong Kong-Shanghai } & 39.58 \\ \text { Beijing-Hong Kong } & 20.54 \\ & \\ \text { London-Shanghai } & 37.91 \\ \text { London-Beijing } & 16.73 \\ \text { London-Hong Kong } & -11.04 \\ \text { New York-Shanghai } & 38.84 \\ \text { New York-Beijing } & 20.22 \\ \text { New York-Hong Kong } & -14.85 \\ & \\ \text { London-New York } & -12.65\end{array}$

